\title{
THE FEBRUARY MEETING IN NEW YORK
}

The three hundred ninety-fourth meeting of the American Mathematical Society was held at Columbia University on Saturday, February 27,1943 . The attendance was approximately two hundred including the following one hundred sixty-seven members of the Society:

C. F. Adler, R. L. Anderson, T. W. Anderson, R. G. Archibald, L. A. Aroian, F. E. Baker, S. F. Barber, M. F. Becker, E. G. Begle, Stefan Bergman, Felix Bernstein, G. D. Birkhoff, Gertrude Blanch, W. M. Bond, C. B. Boyer, H. W. Brinkmann, A. B. Brown, Hobart Bushey, J. H. Bushey, S. S. Cairns, R. H. Cameron, M. D. Clement, L. M. Comer, T. F. Cope, Richard Courant, J. E. Crawford, H. B. Curry, M. D. Darkow, J. A. Daum, Norman Davids, A. S. Day, Jesse Douglas, Arnold Dresden, Nelson Dunford, J. E. Eaton, M. L. Elveback, Paul Erdös, J. M. Feld, W. K. Feller, A. D. Fialkow, Edward Fleisher, W. B. Fite, Tomlinson Fort, R. M. Foster, A. H. Fox, G. A. Foyle, Hans Fried, Orrin Frink, D. L. Fuller, R. E. Fullerton, H. P. Geiringer, B. H. Gere, David Gilbarg, B. P. Gill, A. M. Gleason, M. C. Gray, H. J. Greenberg, C. C. Grove, Laura Guggenbühl, Margaret Gurney, F. C. Hall, N. A. Hall, H. K. Hammer, Gerald Harrison, K. E. Hazard, Olaf Helmer, Einar Hille, T. R. Hollcroft, A. P. Hollo, M. W. Hopkins, Harold Hotelling, S. E. Hotelling; E. M. Hull, Witold Hurewicz, W. H. Ingram, Nathan Jacobson, R. A. Johnson, H. A. Jordan, William Karush, Edward Kasner, S. C. Kleene, J. R. Kline, E. A. Knobelauch, B. O. Koopman, Mark Kormes, Arthur Korn, M. E. Ladue, Solomon Lefschetz, Marguerite Lehr, B. A. Lengyel, D. C. Lewis, Marie Litzinger, E. R. Lorch, Lee Lorch, A. N. Lowan, N. H. McCoy, R. S. McKee, C. C. MacDuffee, H. B. Mann, C. W. Mathews, A. E. Meder, Karl Menger, E. C. Molina, L. W. Niller, H. L. Mintzer, R. E. von Mises, A. K. Mitchell, Deane Montgomery, Parry Moon, Richard Morris, E. J. Moulton, F. J. Murray, C. A. Nelson, Otto Neugebauer, E. N. Nilson, C. O. Oakley, A. F. O'Neill, Oystein Ore, J. C. Oxtoby, E. L. Post, A. L. Putnam, L. L. Rauch, Moses Richardson, R. G. D. Richardson, C. E. Rickart, J. F. Ritt, E. K. Ritter, P. C. Rosenbloom, Raphael Salem, Arthur Sard, Henry Scheffé, I. J. Schoenberg, Alberta Schuettler, I. E. Segal, Seymour Sherman, Max Shiffman, James Singer, P. A. Smith, D. E. Spencer, V. E. Spencer, E. R. Stabler, W. J. Strange, W. C. Strodt, M. M. Sullivan, J. D. Tamarkin, Peter Treuenfels, A. W. Tucker, J. W. Tukey, D. F. Votaw, L. I. Wade, Abraham Wald, G. L. Walker, Wolfgang Wasow, Warren Weaver, André Weil, Louis Weisner, Hermann Weyl, George Whaples, A. P. Wheeler, D. V. Widder, V. A. Widder, John Williamson, H. P. Wirth, Jacob Wolfowitz, Alexander Wundheiler, E. H. Zarantonello, Antoni Zygmund.

The meeting opened at 10 A.M. in two sections, one for papers in Applied Mathematics, Professor J. W. Tukey presiding, and one for papers in Analysis, Vice President C. C. MacDuffee presiding. At the general session immediately following these sections, Professor Deane Montgomery gave an address entitled Transformation groups and spheres. This address had been originally scheduled for the 1942 Annual Meeting which was cancelled because of transportation difficulties. Vice President J. D. Tamarkin presided at this session.

The afternoon program began at 2 P.M. with a general session at 
which Professor Nathan Jacobson gave an address entitled Some topics in the theory of semi-linear transformations. At the close of this address, the presiding officer, Vice President C. C. MacDuffee, asked all to rise in memory of two well known mathematicians who had died recently, E. R. Hedrick and David Hilbert.

At 3:15 P.M. there were two sections, one for papers in Algebra and one for papers in Geometry and Statistics. Professors E. R. Lorch and E. J. Moulton were the presiding officers.

The Council met at 12:30 P.M. in the Men's Faculty Club of Columbia University.

The Secretary announced the election of the following fourteen persons to membership in the Society:

Mr. Louis Fein, Earlham College, Earlham, Ind.;

Professor Fred George Fender, Rutgers University;

Mr. N. Knoll Hersh, Tulane University;

Mr. Clarence Thomas Hill, Ponca City, Okla.;

Professor Carl Holtom, Purdue University;

Mr. Morris E. Levenson, Cooper Union, New York, N. Y.;

Mr. Robert Theodore Luginbuhl, University of Pennsylvania;

Professor Glen Treat Miller, Purdue University;

Professor Joseph Edward Morton, Knox College;

Mr. Kenneth Holden Murphy, West Virginia University;

Mr. Frederick Valentine Pohle, College of Engineering, New York University;

Mr. Edward John Specht, Washington University;

Mr. Allen Frederick Strehler, Ohio State University;

Mr. Joseph Simon Vigder, University of Saskatchewan.

It was reported that the following had been elected as nominees on the Institutional Memberships of the institutions indicated:

University of California: Messrs. Henry Ludwig Alder, Mark W. Eudey, and Herbert Federer, Misses Evelyn Fix and Mildred Lucille Gerini, Messrs. Eric Leo Lehmann and Robert Russell.

Cornell University: Messrs. Clifford D. Firestone and Alfred Milton Peiser.

Harvard University: Messrs. Richard F. Arens, Robert Creighton Buck, Lindley James Burton, Milton Frank Chauner, Carl Cohen, and James Bruce Crabtree, Miss Ellen Elizabeth Fedder, Messrs. Jaime Lifshitz, Roger Conant Lyndon, and Pesi Rustom Masani, Dr. Eduardo Hector Zarantonello.

Johns Hopkins University: Mrs. Ruth Bari.

University of Kentucky: Miss Elsie Temple Church.

Lehigh University: Messrs. James Levert Howell and Charles Miesse.

Northwestern University: Mr. Richard Lence, Miss Mary Ellen Patno.

Pennsylvania State College: Mr. Israel Harold Rose, Mrs. Alice Margaret Crawford Thorpe.

University of Toronto: Messrs. William James Robert Crosby and Bernard Noonan. Wayne University: Miss Jane Cronin.

University of Wisconsin: Messrs. Richard V. Andree and Wulf Gotz.

Yale University: Mr. John George Pocock. 
The following appointments by the President were reported: as auditors of the Society's books for 1943, Professors Samuel Borofsky and A. E. Meder, Jr.; as Chairman of the Committee on Places of Meetings for the period 1943-1945, Professor W. B. Carver; as a member of the Committee on Places of Meetings for 1943, Professor C. R. Adams; as a member of the Committee on the Award of the Bôcher Prize, Professor Emil Artin; as Committee on Arrangements for the 1943 Summer Meeting at Rutgers University, Professors Richard Morris (Chairman), T. R. Hollcroft, B. W. Jones, A. E. Meder, Jr., C. A. Nelson, and E. P. Starke; as members of the War Policy Committee (joint committee with the Mathematical Association of America), Professors M. H. Stone (Chairman), W. D. Cairns, G. C. Evans, L. M. Graves, Marston Morse, Dr. Warren Weaver, and Professor G. T. Whyburn; as members of a subcommittee of the War Policy Committee, to conduct a bureau of available teachers of mathematics for wartime needs, Professors W. D. Cairns, Arnold Dresden, and J. R. Kline; as Committee on Nomination of Officers and Members of the Council for 1944, Professors E. W. Chittenden (Chairman), E. T. Bell, Saunders MacLane, R. L. Moore, and Dean R. G. D. Richardson.

The Secretary reported that the following had been chosen as the voting representatives of editorial committees on the Council for the year 1943: Bulletin-Dean Tomlinson Fort; Transactions-Professor Einar Hille; Colloquium-Professor G. T. Whyburn; American Journal of Mathematics-Professor Hermann Weyl; Mathematical Reviews-Professor Otto Neugebauer. He also reported that Professor G. T. Whyburn had been selected Chairman of the Colloquium Editorial Committee for 1943.

The Council voted to cancel the meeting scheduled for June 1617, 1943, at Oregon State College, in connection with the meetings of the Pacific Division of the American Association for the Advancement of Science.

The Council approved September 11-13 as the dates for the 1943 Summer Meeting at Rutgers University.

The Council adopted the following resolution on the death of Professor E. R. Hedrick:

The Council of the American Mathematical Society records its deep sense of loss in the death on February 3,1943, of Earle Raymond Hedrick. As an active member of the Society during four decades of its unprecedented growth and development, he made contributions which were great in number and varied in character. He gave abundantly of his time, thought, and energy to the Society and served it in the official capacities of Council member, Trustee, Vice President, President, and Editor-inChief of the Bulletin. Through membership on many important committees, both 
within the Society and outside of it, he labored unceasingly toward the advancement of the interests and prestige of mathematics at all levels. His activities in the Mathematical Association of America, The National Council of Teachers of Mathematics, and in numerous engineering and other scientific societies were extensive and outstanding to a degree hard to comprehend in view of his heavy involvement in Society and other responsibilities. Professor Hedrick had a rare combination of broad interests, outstanding skill at logical and thorough analysis, good judgment, and ability to work effectively with other people. These characteristics invariably singled him out and placed him in a position of leadership.

The Secretary presented a report from President Stone, Chairman of the War Policy Committee, which had its first meeting in Philadelphia on February 21, 1943. Members of the Committee and officers of the Society and Association are maintaining effective contacts with various government agencies, with a view to initiating and accelerating actions which make the best use of mathematically trained and qualified personnel under the Army and the Navy Specialized Training Programs and in research connected with the war. The Committee has recommended that every effort should be made to continue scientific meetings, including those arranged on a national scale.

Titles and cross references to the abstracts of the papers read follow below. Papers whose abstract numbers are followed by the letter $t$ were read by title. Papers numbered 1 to 5 were read in the section for Applied Mathematics, papers 6 to 11 in the section for Analysis, papers 12 to 16 in the section for Algebra, and papers 17 to 22 in the section for Geometry and Statistics; papers 23 to 35 were read by title. Paper 9 was read by Professor Cameron, paper 14 by Dr. Lengyel, paper 19 by Professor Kasner. Mr. Ettlinger was introduced by Professor R. L. Moore, and Dr. Schwerdtfeger by Dr. Peter Scherk.

1. H. J. Greenberg: Application of a summability method in solving boundary value problems. (Abstract 49-3-118.)

2. Hilda P. Geiringer: New convergence cases for iteration methods applied to linear equations. (Abstract 49-1-62.)

3. Arthur Korn: On vibrational vortices. (Abstract 49-1-67.)

4. Stefan Bergman: A formula for the stream function in compressible fluid flow. (Abstract 49-3-116.)

5. A. H. Fox: Integral representation of the flow of a compressible fluid around a cylinder. II. (Abstract 49-5-156.)

6. Wolfgang Wasow: On a boundary layer problem for a certain linear partial differential equation. (Abstract 49-1-50.)

7. C. E. Rickart: Decomposition of additive set functions. (Abstract 49-1-99.)

8. W. C. Strodt: Analytic solutions of nonlinear difference equations. Preliminary report. (Abstract 49-1-45.) 
9. R. H. Cameron and W. T. Martin: An expression for the solution of a class of nonlinear integral equations. (Abstract 49-3-110.)

10. N. A. Hall: Confluence of the basic hypergeometric series. (Abstract 49-1-31.)

11. Raphael Salem: Sets of uniqueness and sets of multiplicity. (Abstract 49-3-114.)

12. Gerald Harrison: The structure of algebraic moduls. Preliminary report. (Abstract 49-1-4.)

13. Alexander Wundheiler: An algebraic definition of affine space. (Abstract 49-1-20.)

14. Saunders MacLane and B. A. Lengyel: Integral invariants of a tensor under the symmetry operations of the 32 crystal classes.Preliminary report. (Abstract 49-1-8.)

15. André Weil: Differentiation in algebraic number-fields. (Abstract 49-1-19.)

16. Olaf Helmer: An extension of the elementary divisor theorem. (Abstract 49-1-5.)

17. Mary E. Ladue: Conformal geometry of horn angles of higher order. (Abstract 49-1-74.)

18. Henry Scheffé: On solutions of the Behrens-Fisher problem, based on the t-distribution. (Abstract 49-3-121.)

19. Edward Kasner and John DeCicco: Generalized dynamical trajectories in space. (Abstract 49-3-120.)

20. W. K. Feller: On the general form of the so-called law of the iterated logarithm. (Abstract 49-1-87.)

21. Domina E. Spencer: The tensor representation of the figures of Study's "Geometrie der Dynamen." (Abstract 49-1-79.)

22. Jesse Douglas: Point transformations and isothermal families of curves. II. (Abstract 49-5-160.)

23. E. F. Beckenbach: On conjugate harmonic functions. (Abstract 49-3-109-t.)

24. Joseph Bowden: The quaternary permutation function and a generalization of Newton's binomial theorem and Vandermonde's permutation theorem. (Abstract 49-3-104-t.)

25. Nathaniel Coburn: Boundary value problems in plane plasticity. Preliminary report. (Abstract 49-3-117-t.)

26. L. L. Dines: On linear combinations of quadratic forms. (Abstract 49-3-105-t.)

27. M. G. Ettlinger: On irreducible continuous curves. (Abstract 49-3-122-t.)

28. W. K. Feller: On a probability limit theorem of H. Cramér. (Abstract 49-1-86-t.) 
29. K. O. Friedrichs: On nonlinear vibrations of third order. (Abstract 49-1-61-t.)

30. O. G. Harrold: A decomposition theorem for certain compacta. (Abstract 49-3-123-t.)

31. Einar Hille and Gabor Szegö: Remarks on ergodic theorems. (Abstract 49-5-138-t.)

32. Fritz John: Instability of certain nonlinear vibrations. (Abstract 49-1-65-t.)

33. H. Schwerdtfeger: Identities between skew-symmetric matrices. (Abstract 49-3-106-t.)

34. Gabor Szegö: On the oscillation of differential transforms. IV. Jacobi polynomials. (Abstract 49-3-115-t.)

35. J. W. T. Youngs: On the additivity of the Lebesgue area. (Abstract 49-1-56-t.)

T. R. Hollcroft, Associate Secretary 